\title{
MODEL PENCEGAHAN PRAKTIK KARTEL IMPOR DAGING SAPI DIKAITKAN DENGAN DAYA BELI MASYARAKAT
}

\section{PREVENTION METHOD OF BEEF IMPORT CARTEL PRACTICE RELATED TO PEOPLE'S PURCHASING POWER}

\author{
Idang Riyadi dan \\ T.N. Syamsah
}

\author{
Program Studi Ilmu Hukum Sekolah Pascasarjana \\ Universitas Djuanda Bogor \\ Jl. Tol Ciawi No. 1, Kotak Pos 35, Bogor 16720. \\ Korespondensi : Idang Riyadi, Telp. - \\ e-mail :
}

Jurnal Living Law, Vol. 10, No. 1, 2018

hlm. 78-91

\begin{abstract}
The ability of consumer purchasing power of beef after cartel practice is the effect of the increase of beef price to consumer behavior varies, among others there are buy in fixed amount before and after price increase, there is a decrease the quantity of purchase and some are switching to consume chicken meat. Legal protection is preventively applied to provide legal protection and legal certainty for consumers so that with the prevention of the government in making policy or drafting legislation more carefully so that the interests of consumers or the wider community is not neglected. The purpose of this study is to discuss how to regulate beef imports in Indonesia, the implementation of beef imports categorized as cartels, as well as legal protection for consumers of beef as a result of the practice of imported cartels. The research method used in this research is the normative juridical approach, namely the law is conceptualized as norms, rules, principles or dogmas / jurisprudence. The results of this research are: 1) The regulation on beef import trade in Indonesia has undergone many changes following the market condition, 2) The form of violation of beef import trade in Indonesia occurring in Jabodetabek area is a cartel practice violating Article 11 of Law no. 5 Year 1999, 3) Business activities are not always done honestly by business actors. The act of business actor is not infrequently to the consumer, it is necessary to protect the consumer's rights.
\end{abstract}

Keywords : Cartel Practice, Beef Import, Community Purchasing Power.

Abstrak : Kemampuan daya beli konsumen daging sapi setelah adanya praktik kartel yaitu dampak kenaikan harga daging sapi terhadap perilaku konsumen bervariasi, diantaranya ada yang membeli dalam jumlah yang tetap sebelum dan sesudah kenaikan harga, ada yang mengurangi kuantitas pembeliannya dan ada juga yang beralih mengkonsumsi daging ayam. Perlindungan hukum secara preventif baik diterapkan untuk memberikan perlindungan hukum maupun jaminan kepastian hukum bagi konsumen sehingga dengan adanya tindakan pencegahan tersebut dari pemerintah dalam membuat kebijakan atau menyusun peraturan perundang-undangan. Tujuan penelitian ini membahas tentang bagaimana pengaturan impor daging sapi di Indonesia, pelaksanaan impor daging sapi yang dikategorikan sebagai kartel, serta perlindngan hukum terhadap konsumen daging sapi hasil praktik kartel impor. Metode penelitian yang digunakan dalam penelitian ini adalah pendekatan yuridis normatif. Hasil dari penelitian ini yaitu: 1) Pengaturan mengenai perdagangan impor daging sapi di Indonesia telah mengalami banyak perubahan yang mengikuti keadaan pasar, 2) Bentuk pelanggaran perdagangan impor daging sapi di Indonesia yang terjadi di wilayah Jabodetabek merupakan praktik kartel yang melanggar Pasal 11 UU No. 5 Tahun 1999, 3) Tindakan pelaku usaha tidak jarang merugikan konsumen, maka perlulah hak-hak konsumen itu dilindungi.

Kata Kunci : Praktik Kartel, Impor Daging Sapi, Daya Beli Masyarakat. 


\section{PENDAHULUAN}

Globalisasi merupakan bentuk karateristik hubungan antara penduduk bumi yang melampaui batas-batas konvensional, sepertii negara. Dalam proses tersebut dunia sudah dimanfaatkan

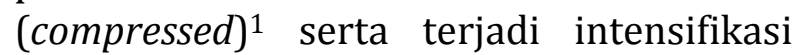
kesadaran dunia sebagai kesatuan utuh. Interdependensi telah menimbulkan proses globalisasi semakin kuat sehingga secara tidak langsung dunia seolah-olah seperti perkampungan besar.

Tujuan pokok yang hendak dicapai untuk menciptakan iklim usaha yang sehat dengan diberlakukan Undang-Undang No. 5 Tahun 1999 tentang Larangan Praktik Monopoli dan Persaingan Usaha Tidak Sehat tersebut adalah dengan menjaga kelangsungan persaingan. Persaingan perlu dijaga eksistensinya demi tercapainya efisiensi, baik itu bagi masyarakat konsumen maupun bagi setiap pelaku usaha.

Persaingan akan mendorong setiap pelaku usaha untuk melakukan usahanya se-efisien mungkin agar bisa menjual barang dan/atau jasa dengan harga yang serendah-rendahnya, sehingga jika setiap pelaku usaha berlomba-lomba untuk paling efisien dalam rangka bersaing dengan pelaku usahaa yang lain, maka pada gilirannya konsumen bisa memilih alternatif terbaik bagi barang dan/atau jasa untuk kebutuhannya, sehingga menciptakan pula efisiensi bagi masyarakat sebagai konsumen. ${ }^{2}$

Undang-Undang No. 5 Tahun 1999 tentang Larangan Praktik Monopoli dan Persaingan Usaha Tidak Sehat memuat tiga kategori tindakan yang dilarang yaitu perjanjian yang dilarang, kegiatan yang dilarang, dan juga posisi dominan. Dalam kategori perjanjian yang dilarang ditentukan ada 10 (sepuluh) tindakan yang tidak dapat dilakukan oleh pelaku usaha,

1 Endang Sutrisno, Hukum dan Globalisasi, Yogyakarta: Penerbit Genta Press, 2007, Hlm. 108.

2 Togar Tandjung, Law and Market Economy, https://lawmark.wordpress.com., Diakses pada tanggal 24 Maret 2017. yaitu oligopoli, penetapan harga, pembagian wilayah, pemboikotan, kartel, trust, oligopsoni, integrasi vertikal, perjanjian tertutup, serta perjanjian dengan pihak luar negeri. ${ }^{3}$

Kategori yang kedua adalah kegiatan yang dilarang menurut Undang-Undang No. 5 Tahun 1999 tentang Larangan Praktik Monopoli dan Persaingan Usaha Tidak Sehat yaitu monopoli, monopsoni, penguasaan pasar, dan persekongkolan. Untuk kategori posisi dominan, bentukbentuk tindakan yang dilarang oleh Undang-Undang No. 5 Tahun 1999 tentang Larangan Praktik Monopoli dan Persaingan Usaha Tidak Sehat, yaitu penyalahgunaan posisi dominan, jabatan rangkap, pemilikan saham, juga penggabungan, peleburan dan pegambilalihan. ${ }^{4}$

Dalam rangka mengawasi pelaksanaan Undang-Undang No. 5 Tahun 1999 tentang Larangan Praktik Monopoli dan Persaingan Usaha Tidak Sehat, maka berdasarkan Pasal 30 Undang-Undang tersebut dibentuklah suatu Komisi Pengawas Persaingan Usaha (KPPU) yang independen terlepas dari pengaruh dan kekuasaan pemerintah serta pihak lain.

Adapun peraturan yang telah dikeluarkan oleh KPPU, antara lain Peraturan Komisi Pengawas Persaingan Usaha No. 1 Tahun 2006 tentang Tata Cara Penanganan Perkara di KPPU. Fungsi utama dari KPPU ada 2 (dua) yaitu Law Enforcement (penegakan hukum persaingan), dan menyampaikan saran pertimbangan kepada pemerintah, terkait dengan kebijakan yang berpotensi bertentangan dengan Undang-Undang No. 5 Tahun 1999 tentang Larangan Praktik Monopoli dan Persaingan Usaha Tidak Sehat. ${ }^{5}$

3 Hermansyah, Pokok-pokok Hukum Persaingan usaha, Jakarta: Kencana Prenada Media, 2008, Hlm. 25.

4 Ibid, Hlm. 38-46.

${ }^{5}$ Redaksi KPPU, Mencegah Kecurangan dari Hulu "Regulatory Review Melalui Jaringan Kerjasama" Majalah Kompetisi Edisi 41/2013, Hlm. 10. 
Fungsi penegakan hukum (law enforcement) bertujuan untuk menghilangkan berbagai hambatan persaingan berupa perilaku bisnis yang tidak sehat. KPPU adalah suatu lembaga independen yang diberikan kewenangan oleh Undang-Undang No. 5 Tahun 1999 tentang Larangan Praktik Monopoli dan Persaingan Usaha Tidak Sehat untuk melakukan pengawasan terhadap pelaksanaan undang-undang tersebut.

Sebagai lembaga pengawas persaingan usaha, KPPU dapat melakukan pemeriksaan dan sekaligus menetapkan ada tidaknya pelanggaran terhadap Undang-Undang No. 5 Tahun 1999 tentang Larangan Praktik Monopoli dan Persaingan Usaha Tidak Sehat yangg dilakukan oleh seseorang atau pelaku usaha. KPPU juga berwenang untuk menjatuhkan sanksi, seperti sanksi administratif, sanksi pidana pokok sebagaimana diatur dalam Pasal 48, serta dapat juga diberikan sanksi pidanaa tambahan seperti diatur dalam Pasal 49 Undang-Undang No. 5 Tahun 1999 tentang Larangan Praktik Monopoli dan Persaingan Usaha Tidak Sehat. ${ }^{6}$

Dalam hal ini juga, KPPU bertindak sebagai lembaga pengawas dalam perkembangan dunia usaha untuk mempertahankan agar persaingan berjalan dengan sehat sehingga tidak terjadi kecurangan-kecurangan yang bisa menghambat (barrier) para pelaku usaha kecil untuk menjalankan usahanya.

Salah satu kasus persaingan usaha tidak sehat yang sedang diinvestigasi oleh KPPU yaitu dugaan adanya perkara kartel daging sapi. Kasus ini menjadi sesuatu yang sudah lama dipelajari KPPU. KPPU telah mempelajarinya sejak 2013-2014, KPPU juga telah mengawasi perkembangan tentang kegiatan kartel daging ini, terutama daging sapi impor dan sapi lokal.

6 Redaksi Hukumonline, Mempersoalkan Sanksi Pidana dalam Hukum Persaingan Usaha, http://www.hukumonline.com/berita/baca/hol218 65/mempersoalkan-sanksi-pidana-dalam-hukumpersaingan-usaha, Diakses pada tanggal 24 Maret 2017.
Memang dalam perkembangan itu tidak mudah menemukan orang yang mau bicara dan dokumen yang menunjukkan adanya kartel. $^{7}$

Lembaga KPPU juga menduga adanya upaya menahan pasokan dalam kasus langkanya daging sapi. KPPU menggelar sidang perdanaa kasus dugaan kartel daging sapi pada Jumat, 6 November 2015 puluhan perusahaan diduga terlibat dalam kasus ini. Majelis Komisi memeriksa saksi Hariyanto, Kepala Rumah Potong Hewan (RPH) Jonggol dan Bogor (PT Sinar Daging Perdana) dan menurut Kepala Bagian Kerja Sama Dalam Negeri dan Humas KPPU Dendy R Sutrisno dalam sidang, saksi menyatakan bahwa pada tahun 2015 RPH Jonggol rata-rata memotong 5-10 ekor per hari namun pada 8-10 Agustus 2015 tidak memotong karena dianggap tidak menguntungkan. "Meski mereka memiliki stok sapi". RPH biasanya lebih memilih sapi yang menguntungkan dari segi harga dan hasil.

Majelis Komisi akan menggelar sidang pemeriksaan lanjutan Kamis, 12 November 2015 dengan agenda pemeriksaan saksi. Dendy menyebut perkara disidangkan dengan No. 10/KPPU-1/2015. Tuduhannya adalah dugaan Pelanggaran Pasal 11 mengenai Kartel dan Pasal 19 mengenai Penguasaan Pasar huruf c Undang-undang No. 5 Tahun 1999 tentang Larangan Praktik Monopoli dan Persaingan Usaha Tidak Sehat dalam Perdagangan Sapi Impor di Jakarta, Bogor, Depok, Tangerang dan Bekasi (Jabodetabek). Sidang perdana ini digelar setelah melewati masa pemeriksaan pendahuluan 15 September 28 Oktober 2015. KPPU menetapkan pemeriksaan lanjutan terhadap perkara yang direncanakan akan berlangsungg 29 Oktober 2015-25 Januari 2016 dengan agenda pembuktian dugaan pelanggaran. Sebanyak 32 perusahaan penggemukan daging sapi atau feedloter diduga terlibat kasus ini. Mereka dianggap menahan stok

\footnotetext{
7 Redaksi KPPU, Penegakan Hukum "KPPU Gelar Sidang Perdana Dugaan Kartel Daging Sapi” Majalah Kompetisi Edisi 50/2015, Hlm. 28-29.
} 
yang masuk ke Rumah Potong Hewan (RPH) sehingga menyebabkan kelangkaan di pasar. ${ }^{8}$

KPPU menduga kelangkaan daging sapi yang terjadi beberapa bulan terakhir ini adalah akibat dari adanya permainan sejumlah pengusaha sapi. Dia menduga praktik kartel tersebut telah direncanakan oleh pengusaha-pengusaha yang terlibat. Dalam periode tertentu sesuai dengan hitungan-hitungan para pengusaha ini, daging sapi ditimbun digudang dan pada saat permintaan melonjak stok tersebut dikeluarkan seperti saat menjelang hari raya, penimbunan terhadap daging sapi jelas melanggar undang-undang. Saat ini dilakukan sejumlah pendalaman terhadap dugaan praktik-praktik nakal sejumlah pengusaha besar. Tim investigasi KPPU menemukan sejumlah RPH pada monopoli perusahaan daging. Bentuk monopoli yang dilakukan adalah penggolontoran dana yang dilakukan perusahaan daging ke RPH. Dana diberikan untuk perawatan mesinmesin dan kebersihan RPH agar bebas dari penyakit pada sapi yang hendak dipotong. Sehingga, pengusaha daging menjual daging lebih mahal. ${ }^{9}$

Sangat jelas bahwa pemerintah dengan tegas mengatur dalam Pasal 11 UndangUndang No. 5 Tahun 1999 tentang Larangan Praktik Monopoli dan Persaingan Usaha Tidak Sehat bahwa pelaku usaha dilarang membuat perjanjian dengan pesaingnya yang bermaksud untuk mempengaruhi harga guna mengatur produksi dan pemasaran suatu barang dan atau jasa yang bisa mengakibatkan terjadinya praktik monopoli dan atau persaingan usaha tidak sehat. Jika terbukti melanggar, maka pelaku usaha dalam hal ini para importir daging sapi akan diberi sanksi denda sebesar Rp. 1 miliar hingga Rp. 25 miliar. Salah satu dari importir

\footnotetext{
8 Ibid.

9 Hukumonline.com, Polri Diminta Cek Dugaan Kartel Daging Sapi, http://www.hukumonline.com/berita/baca/lt5118 c4ce68bab/polri-diminta-cek-dugaan-karteldaging-sapi, Diakses pada tanggal 24 Maret 2017.
}

sudah mengakui adanya terjadi kesepakatan terkait harga sapi dalam asosiasi. ${ }^{10}$

Persoalan kartel daging sapi tersebut menjadi menarik untuk dibahas karena dalam Undang-Undang No. 5 Tahun 1999 tentang Larangan Praktik Monopoli dan Persaingan Usaha Tidak Sehat bentuk pelarangan tertera dalam Pasal 11 ialah rule of reason. Prinsip rule of reason ialah melihat seberapa jauh hal tersebut akan mengakibatkan terjadinya pengekangan persaingan pasar atauu dengan kata lain apabila tidak mengakibatkan adanya indikasi kerugian besar pasar dan pelaku usaha maka tindakan tersebut tidak dilarang. ${ }^{11}$ Jadi harus dibuktikan terlebih dahulu apakah perjanjian itu mengakibatkan persaingan usaha tidak sehat.

Berdasarkan Pasal 35 huruf a UndangUndang No. 5 Tahun 1999 tentang Larangan Praktik Monopoli dan Persaingan Usaha Tidak Sehat, apabila pelaku usaha melanggar Pasal 4 sampai dengan Pasal 16 Undang-Undang No. 5 Tahun 1999 tentang Larangan Praktik Monopoli dan Persaingan Usaha Tidak Sehat maka KPPU akan melakukan penilaian terhadap perjanjian yang dapat mengakibatkan terjadinya praktik monopoli dan atau persaingan usaha tidak sehat. Berdasarkan Pasal tersebut maka jika pelaku usaha terindikasi melakukan kartel maka yang harus dinilai oleh KPPU adalah perjanjiannya. Perjanjian inilah yang akan menjadi alat bukti adanya kartel. Dalam hal ini dugaan praktik kartel dalam impor daging sapi dikarenakan adanya perjanjian para pelaku usaha daging sapi, diduga perjanjiannya dalam bentuk mengadakan kesepakatan untuk menahan stok daging sapi untuk masuk ke dalam RPH sehingga menyebabkan adanya

10 SINDONEWS.com, Polisi Sidik Sindikat Kartel Sapi,

http://nasional.sindonews.com/read/1036738/14

9/polisi-bidik-sindikat-kartel-sapi-1440472924,

Diakses pada tanggal 24 Maret 2017.

11 Munir Fuady, Hukum Antimonopoli Menyongsong Era Persaingan Sehat, Bandung: Citra Aditya Bakti, 2001, HIm. 13. 
kelangkaan daging sapi di pasar dan mengakibatkan harga melonjak tinggi. Jelas hal ini dilarang dimana segala bentuk perjanjian diantara pelaku usaha, baik itu yang tergabung dalam asosiasi maupun tindakan kerjasama lainnya dilarang karena berakibat membatasi atau merusak persaingan.

Komisi Pengawas Persaingan Usaha (KPPU) sudah memvonis 32 (tiga puluh dua) perusahaan penggemukan sapi (feedloter) telah melakukann praktik kartel dan mengatur harga daging sapi di kawasan Jakarta, Bogor, Tangerang, Depok dan Bekasi (Jabodetabek). Keputusan tersebut tertuang dalam Sidang Majelis KPPU di Jakarta, pada Jumat tanggal 22 April 2016.

Praktik kartel yang dilakukan 32 (tiga puluh dua) perusahaan tersebut berupa kesamaan tindakan yang dilakukan oleh para terlapor. Mulai dengan rescheduling sales gang dikatergorikan sebagai penahanan pasokan sapi impor di Jabodetabek. Serta pengaturan pemasaran yang berdampak terhadap kenaikan harga yang tidak wajar yang merugikan kepentingan umum. Ditambah lagi dengan tindakan penahanan pasokan dilakukan para terlapor secara seragam dengan cara tidak merealisasikan jumlah kuota impor sapi yang sudah ditetapkan oleh pemerintah. ${ }^{12}$

Komisioner KPPU mengatakan bahwa vonis KPPU saja belum cukup untuk memperbaiki kondisi pasar daging sapi di Indonesia. Harus ada perbaikan kebijakan dari pemerintah itu sendiri. "Pangkal persoalannya ialah statistik pangan Indonesia tidak akurat. Karena basis datanya salah, kebijakan penyediaan stok yang dilakukan menjadii tidak valid juga. Kondisi pasokan yang tak stabil jelas memicu harga pangan, termasuk daging sapi di pasar selalu rentan gejolak.

\footnotetext{
12 "Inilah Daftar Nama 32 Perusahaan Pelaku Kartel Daging Sapi", http://www.suara.com/bisnis/2016/04/23/10255 8/inilah-daftar-nama-32-perusahaan-pelaku-karteldaging-sapi., Diakses pada tanggal 28 Agustus 2017.
}

Berharap pemerintah melalui Kementerian Pertanian segera melakukan evaluasi proses pendataan pangan nasional. Karena tanpa statistik yang tepat dan akurat, kekacauan harga pangan di pasar akan selalu terjadi. ${ }^{13}$

Kemampuan daya beli konsumen daging sapi setelah adanya praktik kartel yaitu dampak kenaikan harga daging sapi terhadap perilaku konsumen bervariasi, diantaranya ada yang membeli dalam jumlah yang tetap sebelum dan sesudah kenaikan harga, ada yang mengurangi kuantitas pembeliannya dan ada juga yang beralih mengkonsumsi daging ayam.

Berdasarkan pemaparan di atas bahwa dalam persaingan usaha, konsumen atau masyarakat bisa dilindungi hak-haknya dari tindakan pelaku usaha yang tidak patut. Berdasarkan Undang-Undang No. 8 Tahun 1999 tentang Perlindungan Konsumen, menurut hemat penulis, hakhak konsumen yang harus dilindungi, jika terjadi kartel kuota impor daging sapi antara lain:

1) Hak untuk dilindungi dari akibat negatif persaingan curang (khususnya kartel kuota impor daging sapi).

2) Hak untuk memperoleh ganti rugi jika terjadi kartel kuota impor daging sapi.

3) Hak untuk memperoleh kebutuhan hidup yang diperlukan (khususnya kebutuhan akan daging sapi).

4) Hak untuk memperoleh penyelesaian hukum akibat perbuatan pelaku usaha (khususnya tindakan kartel kuota impor daging sapi).

Bahwa perlindungan hukum secara preventif baik diterapkan untuk memberikan perlindungan hukum maupun jaminan kepastian hukum bagi konsumen sehingga dengan adanya tindakan pencegahan tersebut pemerintah dalam membuat kebijakan atau menyusun peraturan perundang-undangan lebih hatihati sehingga kepentingan konsumen atau masyarakat luas tidak terabaikan. 
Setelah melihat uraian latar belakang penelitian tersebut di atas maka penulis dalam penelitian inii mengambil judul tentang: "MODEL PENCEGAHAN PRAKTIK KARTEL IMPOR DAGING SAPI DIKAITKAN DENGAN DAYA BELI MASYARAKAT".

Berdasarkan latar belakang penelitian di atas, maka penulis dapat mengidentifikasi masalah sebagai berikut:

1. Bagaimana pengaturan impor daging sapi di Indonesia?

2. Bagaimana pelaksanaan impor daging sapi di Indonesia yang dapat dikategorikan sebagai kartel berdasarkan UU No. 5 Tahun 1999?

3. Bagaimana perlindungan hukum yang berkeadilan terhadap konsumen akibat praktik kartel kuota impor daging sapi?

\section{METODE PENELITIAN}

Metode penelitian yang digunakan dalam penelitian ini adalah pendekatan yuridis normatif, yaitu hukum dikonsepsikan sebagai norma, kaidah, asas atau dogma-dogma/yurisprudensi.

\section{PEMBAHASAN}

\section{A. PENGARUH PRAKTIK KARTEL TERHADAP DAYA BELI MASYARAKAT}

Impor merupakan kegiatan memasukkan barang ke dalam daerah pabean diatur dalam Pasal 1 angka 8 Peraturan Menteri Perdagangan No. 59 Tahun 2016 tentang Ketentuan Ekspor dan Impor Hewan dan Produk Hewan. Indonesia memiliki beberapa peraturan yang mengatur kegiatan ekspor-impor di bidang pangan terutama sapi, yaitu:

a. Undang-Undang No. 41 Tahun 2014 tentang Perubahan Atas UndangUndang No. 18 Tahun 2009 tentang Peternakan dan Kesehatan Hewan. Impor sapi berawal dari Pasal 36B.

b. Peraturan Menteri Perdagangan Republik Indonesia No. 59 Tahun 2016 tentang Ketentuan Ekspor dan Impor Hewan dan Produk Hewan.
Impor diatur secara lebih rinci dalam peraturan ini. Peraturan ini mengatur tentang teknis impor sapi.

c. Peraturan Pemerintah No. 4 Tahun 2016 tentang Pemasukan Ternak dan/atau Produk Hewan Dalam Hal Tertentu yang Berasal dari Negara atau Zona Dalam Suatu Negara Asal Pemasukan.

Peraturan ini mengatur tentang syaratsyarat hewan atau produk hewan yang diperbolehkan masuk ke dalam wilayah Indonesia yang berasal dari zona tertentu yang telah memenuhi syarat. Hewan atau produk hewan yang boleh masuk ke dalam wilayah Indonesia harus diperiksa dan dinyatakan tidak terdapat penyakit kuku dan mulut maupun penyakit lainnya demi menjaga kualitas protein hewani yang dikonsumsi masyarakat Indonesia.

Pemerintah membuat kebijakan untuk membatasi kuota impor baik sapi bakalan maupun daging sapi yang berbentuk Program Swasembada Daging Sapi (PSDS) untuk menyelamatkan ketergantungan terhadap impor sapi pada tahun 2014. PSDS ini bertujuan untuk meningkatkan sumber daya sapi lokal yang selama ini tidak mampu bersaing. Kebijakan PSDS ini membuat pasar domestik menjadi tidak efisien karena cenderung dapat menciptakan praktik monopoli di Indonesia. Sistem kuota ini mengakibatkan pasar terdistorsi serta membuat harga daging melonjak. Pemerintah harus berani membuka keran impor seluas-luasnya kepada semua pihak yang berminat dan mampu mengimpor sapi yang bertujuan untuk membentuk struktur pasar persaingan sempurna (perfect competition) di perdagangan (daging) sapi sehingga semua pemasok menjadi price taker, yang artinya tidak ada satupun pemasok yang mampu memanipulasi harga karena setiap pemasok hanya menguasai sebagian kecil pangsa pasar.

Indonesia harus bisa segera lepas dari belenggu oligopoli dan kartel, agar konsumen dapat menikmati harga daging 
yang wajar, yaitu yang tidak jauh di atas negara-negara tetangga seperti Malaysia atau Singapura yang sudah lebih sejahtera dari Indonesia. Penurunan harga daging di Indonesia akan membantu meningkatkan konsumsi daging masyarakat yang masih rendah.

\section{B. MODEL PENCEGAHAN PRAKTIK KARTEL IMPOR DAGING SAPI}

Kegiatan impor sapi berhubungan erat dengan para pelaku usaha, dalam hal ini importir atau perusahaan penggemukan sapi (feedloter) yang melakukan persaingan usaha. Persaingan usaha antar para pelaku usaha tersebut bisa berupa persaingan usaha secara sehat maupun tidak sehat. Indonesia mengatur hukum persaingan usaha diantara para pelaku usaha demi mewujudkan persaingan usaha yang sehat atau sempurna yang diatur dalam Undang-Undang No. 5 Tahun 1999 tentang Larangan Praktik Monopoli dan Persaingan Usaha Tidak Sehat. Lembaga pengawas yang mengawasi persaingan usaha dan membantu menegakkan Undang-Undang No. 5 Tahun 1999 tentang Larangan Praktik Monopoli dan Persaingan Usaha Tidak Sehat adalah Komisi Pengawas Persaingan Usaha (KPPU).

Kasus kecurangan dalam kegiatan impor sapi yang melanggar UndangUndang No. 5 Tahun 1999 tentang Larangan Praktik Monopoli dan Persaingan Usaha Tidak Sehat, kasus Kartel Sapi Impor di Wilayah JABODETABEK, yaitu: KPPU menduga adanya pelanggaran larangan praktik monopoli dan persaingan usaha tidak sehat yangg dilakukan oleh 32 (tiga puluh dua) perusahaan pada wilayah JABODETABEK. KPPU mulai melakukan investigasi terkait dugaan tersebut pada tahun 2012. KPPU membuktikan bahwa ke32 perusahaan tersebut melanggar Undang-Undang No. 5 Tahun 1999 tentang Larangan Praktik Monopolii dan Persaingan Usaha Tidak Sehat. Majelis KPPU membacakan bahwa 32 (tiga puluh dua) perusahaan yang berstatus Terlapor, terbukti melanggar Pasal 11 dan Pasal 19 huruf c Undang-Undang No. 5 Tahun 1999 tentang Larangan Praktik Monopoli dan Persaingan Usaha Tidak Sehat pada tanggal 22 Maret. Para Terlapor dihukum untuk membayar denda yang bervariasi, mulai dari Rp 71 juta hingga Rp 21 miliar. KPPU menemukan fakta adanya kesepakatan yang dilakukan para pengusaha dengan difasilitasi Asosiasi Produsen Daging dan Feedlot Indonesia (APFINDO). Majelis menemukan serangkaian pertemuan yang pada akhirnya menunjukkan kesamaan tindakan yang dilakukan oleh para Terlapor.

Alat bukti petunjuk yang ditemukan KPPU dalam kasus tersebut adalah:

1) KPPU menemukannya adanya kesepakatan yangg dilakukan para pengusaha dengan difasilitasi Asosiasi Produsen Daging dan Feedlot Indonesia (APFINDO).

2) Ditemukan faktaa rescheduling sales yang dikategorikann sebagai penahanan pasokann sapi impor di wilayah Jabodetabek.

3) Ditemukan fakta pengaturan pemasaran yangg berdampak pada kenaikan harga yang tidak wajarr dan merugikan kepentingan umum.

4) Terdapat adanya afiliasii diantara para pelaku usaha.

5) Fakta menunjukkan harga sapi lokal untuk keperluan daging di Jabodetabek lebih tinggii dari sapi impor sehingga hal ini diduga merupakan hambatan pasar bagi pelaku usaha lokal memasok sapi ke wilayah tersebut.

Majelis KPPU membacakan bahwa 32 (tiga puluh dua) Terlapor terbukti melakukan pelanggaran Pasal 11 dan Pasal 19 huruf c Undang-Undang No. 5 Tahun 1999 tentang Larangan Praktik Monopoli dan Persaingan Usaha Tidak Sehat.

Proses investigasi atas dugaan kartel daging sapi ini sudah dilaksanakan sejak tahun 2013 hingga 2015. KPPU sudah melakukan kunjungan langsung ke RPH 
dan juga di sejumlah feedloter. KPPU menemukan fakta-fakta di lapangan dan dalam rapat komisioner memutuskan bahwa investigasi dugaan kasus daging ini dijadikan sebagai perkara baru yang akan disidangkan di KPPU.

Berdasarkan Pasal 11 Undang-Undang No. 5 Tahun 1999 yang mengatur tentang larangan kartel ditentukan bahwa:

"Pelaku usaha dilarang membuat perjanjian dengan pelaku usaha pesaingnya yang bermaksudd untuk mempengaruhi harga dengan mengatur produksi dan atau pemasaran suatu barang dan atau jasa, yang dapat mengakibatkan terjadinya praktik monopoli dan atau persaingan usaha tidak sehat."

Meskipun tidak ada definisi yang tegas tentang kartel pada Undang-Undang Larangan Praktik Monopoli, dari Pasal 11 bisa dikonstruksikan bahwa kartel merupakan perjanjian horizontal untuk mempengaruhi harga dengan mengatur produksi dan atau pemasaran suatu barang dan atau jasa, yang bisa mengakibatkan terjadinya praktik monopoli dan atau persaingan usaha tidak sehat.

Apabila kita telaah kasus dugaan kartel dalam impor daging sapi yang dilakukan oleh para pelaku usaha daging sapi ini, maka kita dapat melihat apakah kriteria atau unsur dalam Pasal 11 telah terpenuhi sehingga perjanjian tersebut layak dibatalkan karena termasuk dalam kategori perjanjian yang dilarang. Berdasarkan BW suatu perjanjian haruslah:

1. Mempunyai diperbolehkan.

2. Tidak bertentangan dengan ketertiban umum.

3. Dilakukan dengan itikad baik.

4. Sesuai dengan asas-asas kepatutan.

5. Sesuai dengan kebiasaan.

Dalam hal ini jelas bahwa adanya perjanjian kartel itu sendiri bertentangan dengan ketertibann umum, sebab dapat menciptakan kondisi adanya persaingan usaha tidak sehat. Selain itu perjanjian kartel juga dilakukan dengan itikadd baik antara pelaku usaha sebab bertujuan untuk mendistorsi pasar.

Adapun karakteristik dari kartel yaitu pertama, terdapat konspirasi antara beberapa pelaku usaha. Kedua, melakukan penetapann harga. Ketiga, agar penetapan harga dapat berjalan efektif, maka dilakukan pula alokasi terhadap konsumen, produksi atau wilayah pemasaran. Keempat, adanya perbedaan kepentingan diantara pelaku usaha misalnya karena perbedaan biaya. Dalam hal ini apabila di lihat dari karakteristik kartel itu sendiri sangatlah wajar apabila praktik kartel itu dilarang karena praktik kartel dalam bentuk apapun pasti akan berujung pada kondisi yang merugikan konsumen. Praktik akan menutup adanya peluang bagi masuknya inovasi maupun perusahaan (pendatang baru) yang bisa menawarkan harga lebih murah dan pelayanan yang lebih baik.

Hal ini tentu akan membawa kerugian bagi para pelaku usaha lain terutama pelaku usaha kecil, begitu juga bagi konsumen akan mendapat kerugian karena produsen (perusahaan) dapat mempermainkan distribusi barang atau jasa dan menetapkan harga sesuai yang dikehendaki pelaku usaha dan pada akhirnya perekonomian hanya akan dipengaruhi oleh kekuatan para pelaku usaha besar tersebut.

Tujuan umum dari persaingan usaha ialah terkait dengan beberapa fungsi yaitu:

a. Membentuk desentralisasi kekuatan ekonomi.

Persaingan usaha yang berfungsi dengan baik mengakibatkan desentralisasi kekuatan ekonomi. Suatu tatanan ekonomi yang mampu memberikan kepuasan kepada semua pihak, jika tidak ada pelaku usaha yang dengan kekuatan ekonominya mampu menggantikan mekanisme penyeimbang kepentingan dalam tawar menawar perjanjian dengan penentuan sepihak.

b. Mengemban fungsi politik industrial yang mendorong usaha kecil menengah. 
Hal ini merupakan akibat dari terpolanya sistem desentralisasi kekuatan ekonomi yang merata dan tidak terpusat pada satu kekauatan ekonomi saja.

c. Memberikan alokasi yang optimal pada faktor ekonomi.

Persaingan usaha yang sehat memungkinkan alokasi optimal dari faktor ekonomi. Hal ini berarti bahwa faktorfaktor produksi dialirkan ke proses produksi barang-barang yang umumnya paling dibutuhkan atau diharapkan oleh konsumen. Di sisi lain faktor-faktor produksi tersebut masing-masing dimanfaatkan di bagian di mana hasil khususnya yaitu produktifitas mencapai titik maksimum, karena disanalah pelaku usaha mendapatkan manfaat maksimal dari pengolahan faktor produksi dan memperoleh keuntungan yang sepadan. Penggunaan faktor produksi yang efisien ini mencegah pemborosan penggunaan sumber daya alam dalam perekonomian. Dengan itu juga sekaligus perekonomian hanya akan mengahasilkan barang-barang yang membawa manfaat maksimal bagi konsumen.

d. Persaingan usaha yang sehat akan menimbulkan kedaulatan konsumen dalam pemilik produk. Konsumen bisa bebas untuk memilih produk-produk dengan kualitas dan harga yang terbaik bagi mereka.

e. Sebagai salah satu instrumen perlindungan konsumen. Karena persaingan usahaa antar pelaku usaha, mendorong para pelaku usaha untuk menawarkan produk dengan kualitas yang terbaik dengan harga serendah mungkin (fungsi pendorong).

f. Persaingan usaha sehat dapat berfungsi mendorong perkembangan teknologi.

Untuk mendapat keberhasilan dalam persaingann usaha, maka para pelaku usaha didorong untuk melakukan pengembangan teknologi baru dan meningkatkan produktifitasnya melalui inovasi.
Sebuah persaingan usaha yang berfungsi dengan baik memungkinkan pelaku pasar untuk tampil secara otonom di pasar. Masing-masing pelaku usaha dapat menentukan tindakan bisnisnya tanpa tergantung pada campur tangan atau pengaruh pihak lain. Sehingga sepenuhnya tergantung pada mekanisme pasar. Akhirnya dengan semakin ketat persaingan usaha akan mengakibatkan harga yang ditawarkan kepada konsumen juga semakin rendah.

Keseimbangan dalam hukum dilandasi adanya kenyataan disparitas di mana suatu kasus yang sama, hukum tidak boleh dibenarkan untuk menerapkan peraturan yang berbeda dalam masyarakat, oleh sebab itu diperlukan suatu sistem pengaturan yang dapat melindungi pihak yang mempunyai posisi yang tidak menguntungkan.

Dengan diterapkannya asas keseimbangan dalam praktik persaingan usaha, maka para pelaku usaha dapat menjalankan kegiatannya secara adil, tidak terjadi kemungkinan pemusatan kekuatan ekonomi pada satu pihak saja, para pengusaha akan menerapkan efisiensi produksi maupun pemasaran hasil, dan konsumen mempunyai banyak pilihan dalam menentukan barang yang akan dibeli dengan harga serendah mungkin.

\section{PERLINDUNGAN HUKUM YANG BERKEADILAN TERHADAP KONSUMEN AKIBAT PRAKTIK KARTEL KUOTA IMPOR DAGING SAPI}

Saat ini, daging sapi memiliki harga yang tinggi jauh dari harga pasar. Harga daging sapi yang meningkat dengan cara yang tidak wajar membuat konsumen atau masyarakat mengalami kerugian, di mana kondisi demikian diindakasikan karena tindakan kartel. Kartel impor daging sapi merupakan salah satu perjanjian yang dilarang dalam perundang-undang, mengingat dampaknya yang sangat besar bagi ekonomi yang bertujuan memberi 
kesejahteraan kepada masyarakat khususnya konsumen yang mempunyai kedudukan yang sangat lemah. Tindakan persaingan yang buruk dalam kartel ini seharusnya mendapat perhatian yang besar dari pemerintah, dikarenakan tindakan kartel ini masih sangat sulit untuk dibuktikan dan kajian tentang kartel ini masih sangat minim.

Karena tindakan dalam kartel atau tindakan dalam persaingan usaha tidak selalu mengarah pada hal-hal yang positif, maka hal seperti ini sudah seharusnya perlindungan hukum diberikan bagi konsumen. Bentuk perlindungan hukum yang dimaksud adalah mengatur secara tersendiri mengenai persoalan tersebut dalam peraturan perundang-undangan, yang bisa memberikan batasan tentang pengertian, jenis, pengembangan, pembelian maupun cakupan tentang halhal yang terkait untuk memperjelas mengenai tindakan kartel terutama kartel impor daging sapi yang diperkirakan terindikasi kartel serta mempertegas perlindungan atau payung hukum yang memberikan jaminan kepastian hukum terhadap konsumen.

Berdasarkan pemaparan di atas bahwa dalam persaingan usaha, konsumen atau masyarakat bisa dilindungi hak-haknya dari tindakan pelaku usaha yangg tidak patut. Berdasarkan Undang-Undang No. 8 Tahun 1999 tentang Perlindungan Konsumen, menurut hemat penulis, hakhak konsumen yang haruss dilindungi, jika terjadii kartel impor daging sapi antara lain:

1) Hak untuk dilindungii dari akibat negatif persaingan curang (khususnya kartel impor daging sapi).

2) Hak untuk memperolehh ganti rugi jika terjadi kartel impor daging sapi.

3) Hak untuk memperolehh kebutuhan hidup yang diperlukan (khususnya kebutuhan akan daging sapi).

4) Hak untuk memperolehh penyelesaian hukum akibat perbuatan pelaku usaha (khususnya tindakan kartel impor daging sapi).

Menurut hemat penulis, perlindungan hukum secara preventif baik diterapkan untuk memberikan perlindungan hukum maupun jaminan kepastian hukum bagi konsumen sehingga dengan adanya tindakan pencegahan tersebut pemerintah dalam membuat kebijakan atau menyusun peraturan perundang-undangan lebih hatihati sehingga kepentingan konsumen atau masyarakat luas tidak terabaikan.

Mengingat banyaknya tindakan pelaku usaha yang dapat merugikan konsumen, maka sangat perlu bagi konsumen untuk memahami hukum yang mengatur tentang persaingan usaha untuk melindungi hakhak mereka serta mampu untuk melakukan perlawanan hukum yang berlaku untuk menjerat pelaku usaha curang. Adapun sanksi bagi para pelakuu usaha curang dalam menjalankan bisnisnya yang diatur dalam ketentuan perundang-undanagan, yaitu Undang-Undang No. 5 Tahun 1999 tentang Larangan Praktik Monopoli dan Persaingan Usaha Tidak Sehat, yang berisikan sanksi administratif, pidana pokok dan pidana tambahan.

1. Sanksi Administratif

Tindakan administratif ini diatur dalam Pasal 47 ayat (1) dan ayat (2)

2. Sanksi Pidana Bagi Pelaku Usaha

Dalam Undang-Undang No. 5 Tahun 1999 tentang Larangann Praktik Monopoli dan Persaingan Usaha Tidak Sehat, sanksi pidana dapat dikenakan terhadap pelaku usaha yang melanggar hukum persaingan usaha dapat berupa pidana pokok dan pidana tambahan.

Penjatuhan pidana tersebut dilakukan dalam hal:

a. Pelaku usaha tidakk melaksanakan putusan Komisi yang berupa sanksi administratif (Pasal 44 ayat (4) Undang-Undang No. 5 Tahun 1999).

b. Pelaku usaha menolak untuk diperiksa, menolak untuk memberikan informasi yang 
diperlukann dalam penyelidikan dan/pemeriksaan (Pasal 41 ayat (2) Undang-Undang No. 5 Tahun 1999).

Adapun macam-macam pidana yang bisa dijatuhkan kepada pelakuu usaha yang melakukann kegiatan usaha yangg tidak sesuai atau curang, antara lain:

1) Sanksi Pidana Pokokk Bagi Pelaku Usaha.

Sanksi pidana pokokk diatur dalam Pasal 48 ayat (1), (2) dan (3) .

2) Sanksi Pidana Tambahann Bagi Pelaku Usaha.

Sanksi pidana tambahan diatur dalam Pasal 49 Undang-Undang No. 5 Tahun 1999 tentang Larangann Praktik Monopoli dan Persaingan Usaha Tidak Sehat, dengan menunjuk ketentuan Pasal 10 Kitab Undang-undang Hukum Pidana (KUHP), terhadap pidana sebagaimana diatur dalam Pasal 49 dapat dijatuhkan pidana tambahan berupa:

a. Pencabutan izin usaha, atau

b. Larangan kepada pelakuu usaha yang telah terbuktii melakukan pelanggaran terhadap Undang-Undang No. 5 Tahun 1999 tentang Larangann Praktik Monopoli dan Persaingann Usaha Tidak Sehat akan menduduki jabatan direksi atau komisariss sekurangkurangnya 2 (dua) tahun dan selamalamanya 5 (lima) tahun, atau

c. Penghentian kegiatan atau tindakann tertentu yang menyebabkann timbulnya kerugian padaa pihak lain.

Fenomena kartel yang terjadi saat ini tentu sangat meresahkan konsumen, apalagi melonjaknya harga dagingg sapi yang sampai sekarang ini belum menemukan penyelesaian, dari kondisi yang terjadi akhir-akhir ini, terlihat bahwa dalam menjalankan kegiatan bisnis atau usahanya pelaku usaha melakukan penekanan jumlah produksi di pasaran dengan menutup gudang mereka, sehingga produksi pangan seperti daging sapi di pasaran tidak berlebih. Hal tersebut tentu saja menyebabkan lonjakan harga daging sapi.

Berdasarkan hal-hal di atas tersebut, penulis menyimpulkan akibat yang ditimbulkann terhadap konsumen, apabila kartel impor daging sapi itu terjadi atau ditemukan kecurangan dalam produksi jumlah daging sapi di pasaran akan menimbulkan dampak atau akibat sebagai berikut:

1) Konsumen tidak mampu memenuhi kebutuhan hidupnya atau kebutuhan akan daging sapi.

2) Konsumen tidak bisa membeli daging sapi sesuai dengan harga persaingan.

3) Semakin lemahnya posisi tawar konsumen untuk melindungi dirinya.

4) Konsumen mengalami kerugian.

5) Konsumen semakin tidak mampu memprediksi laju kegiatan pelaku usaha yang setiap saat dapat merugikan.

Dengan adanya tindakan tersebut maka konsumen dapat meminta pertanggungjawaban pelaku usaha sebagai akibat hukum dari tindakan yang dilakukan oleh pelaku usaha sesuai dengan peraturan perundang-undangan yang berlaku.

Berdasarkan hal tersebut, penulis beranggapan bahwa indikasi kartel impor daging sapi mulai terlihat, maka jika hal itu terjadi pelaku usaha seharusnya di berikan sanksi sesuai dengan peraturan perundang-undangan yang berlaku. Yang menjadi persoalan saat ini apakah sanksi yang diterapkan dalam perundangundangan sudah mampu memberikan proteksi. Jika kita lihat dari banyaknya kasus kartel di Indonesia, peraturan perundang-undangan yang mengatur tentang perjanjian curang (kartel) masih lemah. Lembaga khusus yang ditunjuk sebagai pegawas persaingan usaha yaitu Komisi Pengawas Persaingan Usaha, memiliki posisi yang lemah bahkan cendrung tidak memiliki taring. Sanksisanksi yang diberikan masih sangat lemah, terutama pengenaan denda yang jumlahnya sangat kecil bila dibandingkan 
dengan kerugian yang ditimbulkan oleh pelaku usaha yang melakukan usaha curang.

Perlu adanya penguatan terhadap kedudukan KPPU dalam konstitusi hal ini untuk memberikan kepastian hukum bagi KPPU dalam menjalankan tugasnya serta memberikan kepastian hukum bagi konsumen. Hal tersebut seirama dengan teori Hans Kelsen bahwa hukum yang tertinggi adalah aturan yang tertulis yang dapat memberikan jaminan bagi masyarakat.

Sebagaimana pandangan Jeremy Bentham yang menyatakan bahwa tujuan pembentukan hukum adalah untuk menjamin kebahagiaan dan kenyamanan untuk orang lain atau orang banyak. Dengan demikian dalam pembentukan peraturan perundang-undangan haruslah memberikan kepastian dan kemanfaatan hukum bagi banyak pihak dan perlu adanya kordinasi yang jelas antara pemerintah dan aparat penegak hukum dalam menegakan hukum. Sehingga dengan terjalinya kerjasama yang baik dan kepastian hukum dalam peraturan perundang-undangan akan dapat mengurangi praktik kartel serta mencegah munculnya praktik-praktik kartel lainnya khususya kartel impor daging sapi yang terjadi di Jabodetabek.

\section{KESIMPULAN}

Berdasarkan uraian pembahasan di atas, maka dapat diperoleh kesimpulan sebagai berikut:

1. Pengaturan mengenai perdagangan impor daging sapi di Indonesia telah mengalami banyak perubahan yang mengikuti keadaan pasar. Perubahan kebijakan impor daging sapi yang paling menonjol adalah Program Swasembada Daging Sapi (PSDS). PSDS bertujuan membatasi kuota impor baik sapi bakalan maupun daging sapi untuk meningkatkan sumber daya sapi lokal, namun program ini dianggap gagal dan justru menyebabkan maraknya praktik monopoli dan persaingan usaha tidak sehat diantara para pelaku usaha, sehingga pemerintah mencabut program ini pada tahun 2016. Kebijakan impor sapi yang digunakan oleh Menteri Pertanian saat ini adalah Peraturan Menteri Pertanian (Permentan) Nomor 16 Tahun 2016 tentang Pemasukan Ternak Ruminansia Besar ke Dalam Wilayah Republik Indonesia.

2. Bentuk pelanggaran perdagangan impor daging sapi di Indonesia yang terjadi di wilayah Jabodetabek merupakan praktik kartel yang melanggar Pasal 11 Undang-Undang Nomor 5 Tahun 1999 tentang Larangan Praktik Monopoli dan Persaingan Usaha Tidak Sehat. Praktik kartel tersebut ditangani langsung oleh Komisi Pengawas Persaingan Usaha (KPPU) yang secara langsung memiliki wewenang terhadap kasus tersebut. Majelis KPPU telah memutuskan bersalah 32 (tiga puluh dua) terlapor dalam kasus kartel impor daging sapi di wilayah Jabodetabek. Unsur yang terbukti yaitu unsur yang bertujuan untuk mempengaruhi harga, pemerintah juga mengeluarkan kebijakan dengan hanya memperbolehkan impor sapi ekor sapi, sedangkan kebutuhan impor sapi akibat kurangnya pasokan sapi lokal saat ini. Maka pengurangan impor sapi pasti berdampak hal ini juga yang menyebabkan salah satu kelangkaan pasokan daging sapi.

3. Kegiatan usaha tidaklah selalu dilakukan secara jujur oleh pelaku usaha. Tindakan pelaku usaha tidak jarang merugikan konsumen, maka perlulah hak-hak konsumen itu dilindungi. Berdasarkan Pasal 4 Undang-Undang Nomor 8 Tahun 1999 tentang Perlindungan Konsumen, konsumen berhak untuk dilindungi dari akibat negatif persaingan curang khususnya kartel impor daging sapi dan memiliki hak-hak lain, yaitu hak untuk memperoleh ganti rugi jika 
terjadi kartel impor daging sapi, hak untuk memperoleh kebutuhan hidup yang diperlukan khususnya kebutuhan daging sapi, dan hak untuk memperoleh penyelesaian hukum akibat perbuatan pelaku usaha khususnya tindakan kartel impor daging sapi demi terwujudnya prinsip keadilan bagi para pihak antara pelaku usaha kartel dengan pelaku usaha lainnya dan pelaku usaha kartel dengan masyarakat sebagai konsumen.

\section{SARAN}

1. Pelaku Usaha dalam menjalankan usahanya harus lebih memperhatikan ketentuan-ketentuan hukum yang sesuai dengan asas-asas persaingan usaha yang sehat agar dalam menjalankan usaha terciptanya keseimbangan dalam hukum baik antar sesama pelaku usaha maupun masyarakat sebagai konsumen serta diperlukannya suatu sistem pengaturan yang dapat melindungi pihak yang memiliki posisi yang tidak menguntungkan dalam menjalankan kegiatan usahanya.

2. Pemerintah harus lebih memperhatikan kebutuhan daging sapi sebelum menentukan sistem pembagian kuota yang diterapkan karena bisa menghambat distribusi daging sapi ke masyarakat yang bisa menyebabkan adanya kelangkaan dan mahalnya daging sapi di masyarakat.

3. Diharapkan pemerintah untuk lebih meningkatkan mutu dan kualitas aturan hukum yang memberikan perlindungan hukum terhadap konsumen dan penguatan posisi KPPU dalam konstitusi agar putusan yang dijatuhkan oleh lembaga khusus tersebut dapat mengikat.

\section{UCAPAN TERIMA KASIH}

\section{DAFTAR PUSTAKA}

\section{Buku}

Andi Fahmi Lubis, Hukum Persaingan Usaha: Antara Teks dan Konteks, Jakarta: GTZ, 2009.

Arie Siswanto, Hukum Persaingan Usaha, Jakarta: Ghalia Indonesia, 2002.

Endang Sutrisno, Hukum dan Globalisasi, Yogyakarta: Penerbit Genta Press, 2007.

Hans Kelsen, Teori Hukum Murni : Dasar-dasar Ilmu Hukum Normatif, Bandung: Penerbit Nusamedia, 2007.

Hermansyah, Pokok-pokok Hukum Persaingan usaha, Jakarta: Kencana Prenada Media, 2008.

Jeremy Bentham, An Introduction to The Principles of Morals and Legislation, London: Batoche Books Kichener, 1781.

Munir Fuady, Hukum Antimonopoli Menyongsong Era Persaingan Sehat, Bandung: Citra Aditya Bakti, 2001. 
Philipus M. Hadjon, Perlindungan Hukum Bagi Rakyat Di Indonesia, Sebuah Studi Tentang Prinsip-prinsipnya, Penanganannya oleh Pengadilan dalam Lingkungan Peradilan Umum dan Pembentukan Peradilan Administrasi Negara, Surabaya: PT Bina Ilmu, 1987.

Winarno, Perumusan Asas Keseimbangan Kepentingandalam UU No. 5 Tahun 1999, Tesis Program Magister Ilmu Hukum Universitas Diponegoro Semarang, 2009.

\section{Majalah}

Redaksi KPPU, Mencegah Kecurangan dari Hulu "Regulatory Review Melalui Jaringan Kerjasama” Majalah Kompetisi Edisi 41/2013.

, Penegakan Hukum "KPPU Gelar Sidang Perdana Dugaan Kartel Daging Sapi" Majalah Kompetisi Edisi 50/2015.

\section{Internet}

"Inilah Daftar Nama 32 Perusahaan Pelaku Kartel Daging Sapi", http://www.suara.com/bisnis/2016/04/23/102558/inilah-daftar-nama-32perusahaan-pelaku-kartel-daging-sapi., Diakses pada tanggal 28 Agustus 2017.

"Restrukturisasi Tata Kelola Perdagangan Sapi Membangkitkan Kesejahteraan Peternak Rakyat Serta Meningkatkan Konsumsi Daging", http://www.kadinindonesia.or.id/berita/berita-kadin/200-restrukturisasi-tatakelolaperdagangan-sapi-membangkitkankesejahteraan-peternak-rakyatsertameningkatkan-konsumsi-daging., Diakses pada tanggal 30 Oktober 2017.

Hukumonline.com, Polri Diminta Cek Dugaan Kartel Daging Sapi, http://www.hukumonline.com/berita/baca/lt5118c4ce68bab/polri-diminta-cekdugaan-kartel-daging-sapi, Diakses pada tanggal 24 Maret 2017.

Redaksi Hukumonline, Mempersoalkan Sanksi Pidana dalam Hukum Persaingan Usaha, http://www.hukumonline.com/berita/baca/hol21865/mempersoalkan-sanksipidana-dalam-hukum-persaingan-usaha, Diakses pada tanggal 24 Maret 2017.

SINDONEWS.com, Polisi Sidik Sindikat Kartel Sapi, http://nasional.sindonews.com/read/1036738/149/polisi-bidik-sindikat-kartelsapi-1440472924, Diakses pada tanggal 24 Maret 2017.

Togar Tandjung, Law and Market Economy, https://lawmark.wordpress.com., Diakses pada tanggal 24 Maret 2017. 